\title{
Ethylene and brassinosteroid effect on strawberry ripening after field spray
}

\author{
Ricardo Antonio Ayub ${ }^{1}$, Letícia Reis ${ }^{2}$, Precila Zambotto Lopes ${ }^{3}$, Luane Bosetto ${ }^{4}$
}

Abstract - In contrast to ripening of climacteric fruits knowledge, non-climacteric fruits ripening still poorly understood. In this sense, strawberry (Fragaria $x$ ananassa $\mathrm{L}$. Duch) is a high commercial crop and has an expressive world production that has been used as a model study. Thus, the aim of this study was to evaluate the effect on physicochemical and phytochemical characteristics of strawberry Cv. Camiño Real, in four maturation stages (green, white, pink and red) after the ethylene (Etephon $\left.{ }^{\circledR}\right)$ and brassinosteroid (epi-brassinolide) exogenous spray. The evaluations were carried out at application time (field assay) and after 24h (post-harvest assay). Brassinosteroid application tends to reduce phenolic compounds content mainly in the red stage, whereas ethylene treatment tends to increase supposing that while brassinosteroids reduce phenolic compounds acting to fruit conservation, by the reduction of oxidative stress, increasing antioxidant activity, the ethylene act in fruit ripening leading to senescence. However, for vitamin $\mathrm{C}$ content while brassinosteroid treatment increases ascorbic acid in postharvest for the white fruit, the ethylene treatment do a dramatically increased in vitamin $C$ content to red fruits, showing that although ethylene and brassinosteroids can affect the vitamin $\mathrm{C}$ content, the response can change according to the development stage spray, suggesting that more studies are necessary to understand the hormonal interaction for ascorbic acid production during strawberry ripening.

Index terms: Fragaria x ananassa Duch, Rosaceae, Maturation, Ethephon, Epi-brassinolide.

\section{Efeito do etileno e do brassinoestereoide no amadurecimento do morango após aplicação no campo}

Corresponding author: rayub@uepg.br

Received: May 29, 2017. Accepted : November 28, 2017.

Copyright: All the contents of this journal, except where otherwise noted, is licensed under a Creative Commons Attribution License.

\section{$(\mathrm{cc}) \mathrm{BY}$}

Resumo - Em contraste com o conhecimento sobre a maturação de frutos climatéricos, a maturação de frutos não climatéricos ainda é pouco entendida. Neste sentido, o morangueiro (Fragaria $x$ ananassa) é uma cultura de elevado valor comercial e expressiva produção mundial que vem sendo utilizada como modelo de estudos. Assim, o objetivo deste trabalho foi avaliar o efeito sobre as características físico-químicas e fitoquímicas do morango Cv. Camiño Real, em quatro estádios de maturação (verde, branco, rosa e vermelho), após o spray exógeno de etileno (Etephon ${ }^{\circledR}$ ) e brassinoesteroide (epibrassinolide). As avaliações foram realizadas no momento da aplicação (ensaio de campo) e após 24 h (ensaio pós-colheita). A aplicação de brassinoesteroide reduz o conteúdo de compostos fenólicos no estádio vermelho, enquanto o tratamento com etileno aumenta. Assim, supõe-se que, enquanto os brassinoesteroides diminuem a concentração de compostos fenólicos, atuando na conservação dos frutos pela redução do estresse oxidativo e pelo aumento da atividade antioxidante, o etileno age acelerando o amadurecimento do fruto, levando à senescência. No entanto, para o conteúdo de vitamina $\mathrm{C}$, enquanto o tratamento com brassinoesteroide aumenta o ácido ascórbico na pós-colheita em frutos brancos, o tratamento de etileno aumentou dramaticamente o conteúdo de vitamina $\mathrm{C}$ em frutos vermelhos, mostrando que, embora o etileno e os brassinoesterideos possam afetar o conteúdo de vitamina $\mathrm{C}$, a resposta pode mudar de acordo com o estádio de desenvolvimento, sugerindo que são necessários mais estudos para compreender a interação hormonal para a produção de ácido ascórbico durante o amadurecimento de morangos.

Termos de indexação: Fragaria x ananassa Duch, Rosaceae, Amadurecimento, Ethephon, Epibrassinolídeo. 
According to ethylene production and respiration, the fleshy fruits are classified into climacteric and nonclimacteric. Although involved in several aspects of plant growth, such as seed germination, cell elongation, root initiation, flower development and sexual determination, plant stress, maturation and senescence (MERCHANTE et al., 2013), ethylene is mainly known as "the ripening hormone" because of its known role in climacteric fruits (BAPAT et al., 2010). However, in non-climacteric fruits, such as strawberry, ethylene mediates few metabolic pathways, but, the role of this plant regulator has not yet been elucidated (LOPES et al., 2015; VILLARREAL et al., 2010). By the way ethylene is not the only plant regulator involved in the non-climacteric ripening, suggesting that it is also influenced by other plant growth regulators (MERCHANTE et al., 2013) as Abscisic acid (AYUB et al., 2016) and brassinosteroids (AYUB et al., 2018).

Brassinosteroids are new plant growth regulators that play important roles in cell elongation and division, vascular differentiation, flowering and pollen formation (CLOUSE, 2011), and which has been a lot studied for this role on fruit ripening. Castasterone, a brassinosteroid precursor, remains constant at basal levels during strawberry ripening (SYMONS et al., 2012), leading to the belief that there is not a direct influence in strawberry ripening. However, subsequent studies have shown that inhibition of brassinosteroid delayed red color in ripe strawberry fruits (CHAI et al., 2013), indicating that this regulator may have influence on specific attributes of strawberry maturation, however, evidencing that there is little knowledge about the role of brassinosteroid in strawberry ripening.

Recently, it was observed that brassinosteroid injection in strawberry pink stage increases the receptors and transcription factors expression, but for phytochemical characteristics the brassinosteroid influence mainly starts in the white stage for total sugar and soluble solid and, in addition, there is a positive effect on vitamin $\mathrm{C}$ content and total anthocyanins for the treated red fruits, suggesting that brassinosteroid is involved in strawberry fruit ripening, in different stages, mainly in a phenylpropanoid pathway (AYUB et al., 2018).

In this way, the aim of this study is investigate the influence of ethylene and brassinosteroid during ripening of strawberry (Fragaria x ananassa L. Duch) cv. Camiño Real, analyzing its effects on physicochemical and phytochemical characteristics at harvest and postharvest.

Strawberry plants (Fragaria $x$ ananassa L. Duch. Var. Camino Real) were grown from May to December 2012, outdoors at a commercial property under plastic cover, in Ponta Grossa, state of Parana, latitude $24^{\circ} 59.082^{\prime} \mathrm{S}$, longitude $50^{\circ} 15.903^{\prime} \mathrm{W}$ and altitude $912 \mathrm{~m}$. Fruits were treated and analyzed during four developmental stages: green ( 7 days after anthesis - DAA), white (17 days DAA), pink (21 days DAA), and red (24 days DAA).

Attached fruits in four different development stages were sprinkled at field with Ethylene using 500 ppm ethephon (Ethrel 720 -Bayer) with $0.02 \%$ Tween 20 ; or Brassinosteroid using $0.2 \mu \mathrm{M}$ epibrasinolide (Sigma) with $0.02 \%$ Tween 20 prepared just before using it. To control, it was sprinkled distilled water with $0.02 \%$ Tween 20 (SYMONS et al., 2006). After the field treatment, the fruits were harvested and taken to the laboratory to immediate analysis (Field assay) and after $24 \mathrm{~h}$ analysis (post-harvest assay).

Nine whole fresh fruits were sampled to physicochemical analysis (Firmness, Epidermis surface color, Soluble solids and Titratable acidity), and a sample composed of frozen fruits at $-80{ }^{\circ} \mathrm{C}$ were used to phytochemical analysis (Phenolic compounds, Anthocyanins, Vitamin C and Total sugars). This analyzes were realize according to Ayub et al., (2016) and Lopes et al (2015).

The experiment was carried out in a randomized block design, with three replications, in a $3 \times 2$ factorial scheme, containing 3 treatments (control, ethylene and brassinolide) at two evaluation moments (Field and Postharvest). The results were submitted to Analysis of Variance (ANOVA), and the significant means were compared by the Tukey test $(p \leq 0.05)$ with the aid of the statistical software SISVAR (FERREIRA, 2001). Data were analyzed separately for each stage of development, with no statistical comparison between stages.

For the physical chemical analyzes, there is not a significant difference between the treatments, but only between the assays (field and post-harvest) and development stages. For firmness, we observed the firmness reduction, from $54.36 \mathrm{~N}$ in green fruits to $9.59 \mathrm{~N}$ in red fruits, because during the maturation occur changes like solubilization and depolymerization of pectin that causes pulp softening (VILLAREAL et al., 2008). There is hue angle reduction during the maturation of $105.06^{\circ} \mathrm{h}$ in green fruits to $26.03^{\circ} \mathrm{h}$ in red fruits, demonstrating the increase of light red color in the fruits, mainly by the accumulation of anthocyanins pelargonidin-3-O (Pg3) and cyanidin-3-glucoside (Cy3 glc) (ZHANG et al., 2008) and chlorophyll degradation (VILLARREAL et al., 2010). In addition, there was a trend of increasing soluble solids content, from $6.86^{\circ} \mathrm{Brix}$ in green fruits to $8.99^{\circ} \mathrm{Brix}$ in red fruits, and reduction of the total titrated acidity, from $0.68 \%$ of citric acid in green fruits to $0.48 \%$ of citric acid in red fruits, because the sucrose and polysaccharides degradation of reserve and consumption of organic acids in the Krebs cycle, due to respiration for energy production (VALERO; SERRANO, 2010) (Data not shown).

Similarly, for phytochemical analyzes, there is no differences between treatments for anthocyanin content and total sugars, but only the tendency of increasing 
anthocyanins from 0 in green fruits to $51.71 \mathrm{mg}$ of cianidin3 -glycoside/100 $\mathrm{g}$ fresh pulp weight in red fruits and increasing total sugars from $0.19 \mathrm{~g} / 100$ in green fruits to $0.26 \mathrm{~g} / 100$ in red fruits (Data not shown).

However, for phytochemical analyzes, there is a significant difference between control, brassinosteroid and ethylene treatments for phenolic compounds and vitamin C (Figure 1 and Figure 2). To control fruits by field analyzes, phenolic compounds content shows increase of $22.41 \%$ from green to white fruits, and next reduction of $37.40 \%$ in the pink fruits, until very low levels in red fruits (Figure 1), disagreeing with Jiang et al. (2001), who observed a gradual increase in the content of phenolic compounds during strawberry ripening. The same was observed to postharvest assay. Strawberries are an indisputable source of phenolic compounds, such as flavonoids, phenolic acid derivatives and anthocyanins, which vary in quantity and composition throughout ripening (MARTÍNEZ et al., 2001). The phenolic compounds are synthesized by Phenilpropanoids pathway (MUÑOZ et al., 2011), in which the primary enzyme is phenylalanine ammonialyase (PAL) (SINGH et al., 2010). Thus, considering that the anthocyanin content increased during maturation while the content of phenolic compounds decreased, we can assume that the phenolic content may be related to other forms of phenolic compounds that are not anthocyanins.

To brassinosteroid treatment, in postharvest analysis, the green fruits show reduction of $48.95 \%$ in phenolic compounds content compared to control. Likewise, in red fruits at field analysis, there was a reduction of $32.51 \%$ in the content of phenolic compounds compared to control (Figure 1). However, this result disagrees with Xi et al. (2013), which observed increased activity of PAL, phenolic compounds, anthocyanins and antioxidant capacity in grape berries, other non-climacteric fruit, after field brassinosteroid treatment.

To the ethylene treatment, in field analysis, red fruits shows $74.57 \%$ reduction in phenolic compounds content compared to control, however, for red fruits, the application of ethylene increased $25.27 \%$ phenolic compounds content in field assay and $91.52 \%$ in postharvest analysis (Figure 1), which may be related to the stress caused by exogenous ethylene treatment. According to Xi et al. (2013) the phenylpropanoid pathway and the accumulation of phenolic compounds can be stimulated as a physiological response to a stress condition, therefore, the exogenous application of ethylene would have direct effect. Likewise, we can assume that brassinosteroids may be negatively interfering with the phenylpropanoid pathway, whereas ethylene seems to stimulate, increasing the production of phenolic compounds.

Ascorbic acid is an important antioxidant molecule that acts as a primary substrate in the cyclic pathway for the enzymatic detoxification of free radicals, protecting plants from oxidative stress by elimination of reactive oxygen species (SMIRNOFF; WHEELER, 2000). To vitamin $\mathrm{C}$ content, to control fruits in field assay, had gradual increased the ascorbic acid content during the ripening, from $35.34 \mathrm{mg} / 100 \mathrm{~g}$ in green fruits to $77.27 \mathrm{mg} / 100 \mathrm{~g}$ in red fruits, corroborating with Lee and Kader (2000) that showed the increase of ascorbic acid during ripening, and Lopes et al. (2015), who showed about 70mg/100g of ascorbic acid in strawberry fruits in the red stage (Figure 2). However, with the exogenous application of brassinosteroid, there was reduction of the vitamin C content compared to control, at field assay to white fruits (20.71\%), pink fruits $(34.03 \%)$ and red fruits $(26.09 \%)$ (Figure 2), while to postharvest assay white fruits with brassinosteroid treatment showed a $31.47 \%$ increase in vitamin C content compared to control. Similarly, in tomato fruits, considered a model of climacteric ripening, Zhu et al. (2015) observed an increase in ascorbic acid in fruits treated with brassinosteroid in the initial storage period, relating the brassinosteroid to the fruit quality maintenance. However, ethylene treatment showed that in red fruit, vitamin C content increased 20.66\% compared to control in post-harvest assay (Figure 2). Thus, although ethylene and brassinosteroids can affect strawberry ripening to phenolic compound, we can suggest that brassinosteroids tends to reduce phenolic compounds while ethylene seems act in a contrary way. However, to the vitamin $\mathrm{C}$ content, the response can change according to the development stage spray, suggesting that more studies are necessary to understand the hormonal interaction for ascorbic acid production during strawberry ripening. 


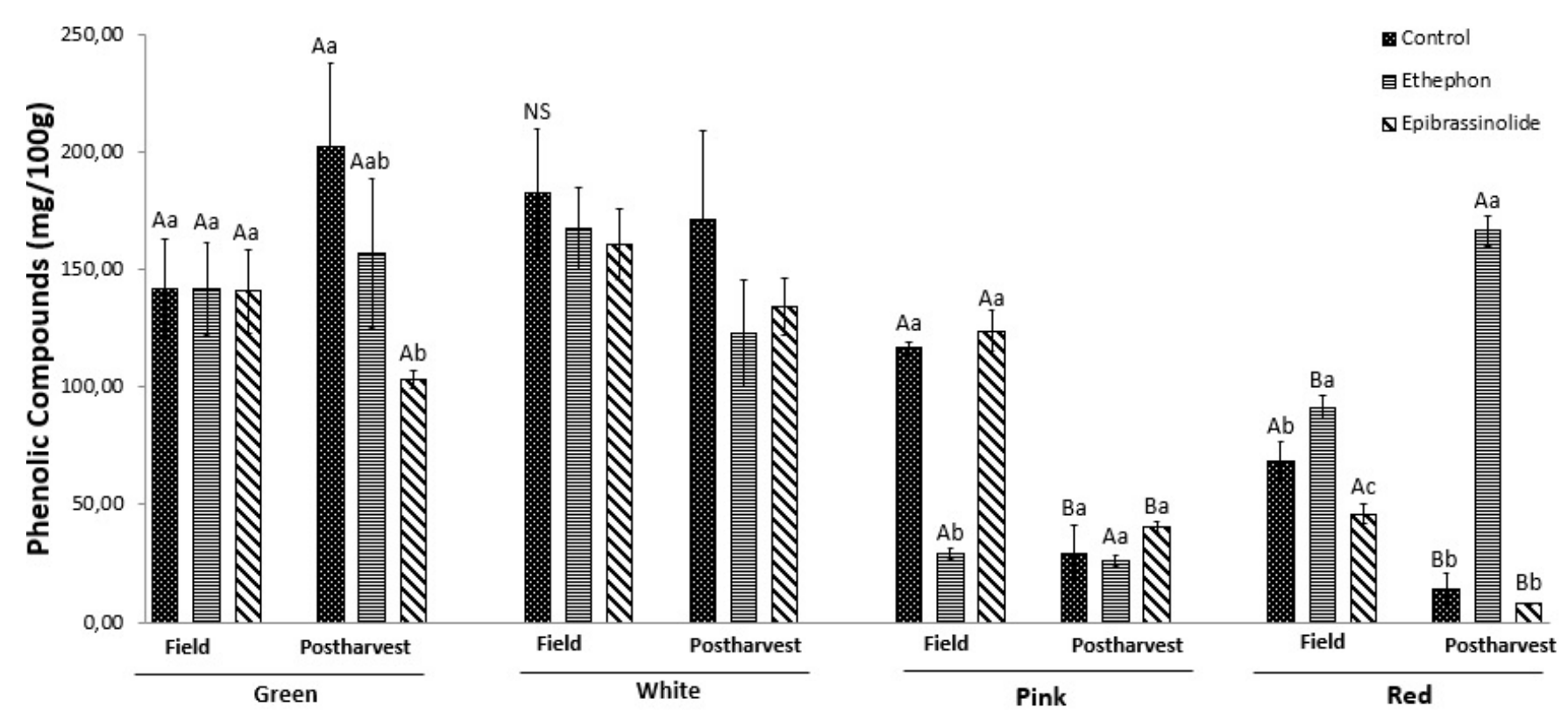

Figure 1. Content of phenolic compounds in strawberry fruits during four maturities (green, white, pink and red), under ethylene or brassinosteroid spray, evaluated at the time (field) and after $24 \mathrm{~h}$ (post-harvest). Same capital letter does not differ between the evaluation (field and post-harvest) for the same treatment within the same maturity. Same lowercase letter does not differ between the treatments for the same time within the same maturity for Tukey test $(\mathrm{p} \leq 0.05)$. There is not statistical between maturities.

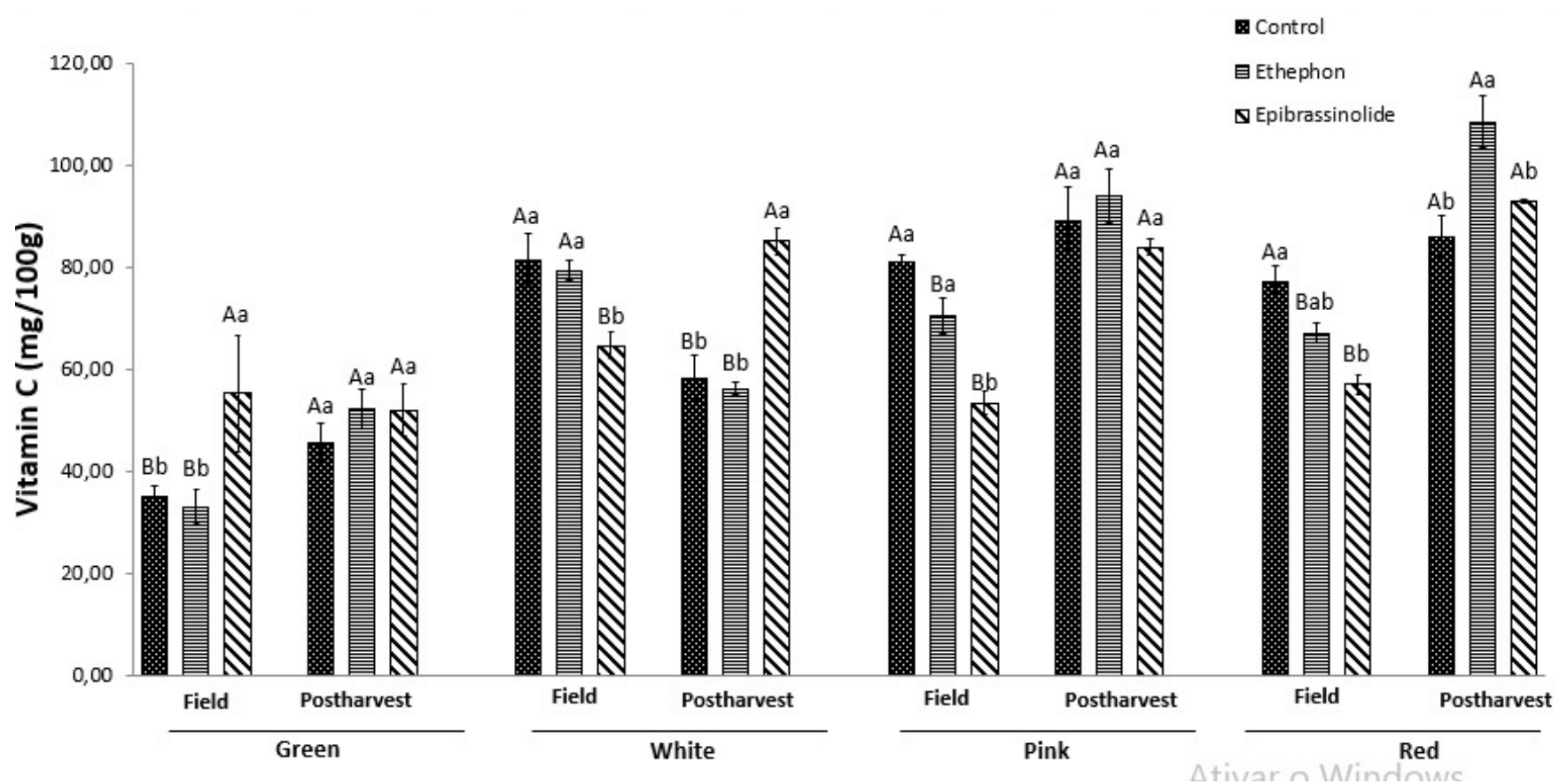

Figure 2. Vitamin C content in strawberry fruits, during four maturities (green, white, pink and red), under ethylene or brassinosteroid spray, evaluated at the time (field) and after $24 \mathrm{~h}$ (post-harvest). Same capital letter does not differ between the evaluation (field and post-harvest) for the same treatment within the same maturity. Same lowercase letter does not differ between the treatments for the same time within the same maturity for Tukey test $(\mathrm{p} \leq 0.05)$. There is not statistical between maturities. 


\section{References}

AYUB, R.A., REIS, L., BOSETTO, L., LOPES, P.Z., GALVÃO, C.W., ETTO, R.M. Brassinosteroid plays a role on pink stage for receptor and transcription factors involved in strawberry fruit ripening. Plant Growth Regulation, Farnham Royal, v.83, n.1, p.159-167, 2018.

AYUB, R.A.; BOSETTO, L.; GALVÃO, C.W.; ETTO, R;. INABA, J.; LOPES, P.Z. Abscisic acid involvement on expression of related gene and phytochemicals during ripening in strawberry fruit Fragaria $\times$ ananassa $\mathrm{cv}$. Camino Real. Scientia Horticulturae, Amsterdam, v.203, n.1, p.178-184, 2016.

BAPAT, V.A.; TRIVEDI, P.K.; GHOSH, A.; SANE, V.A.; GANAPATHI, T.R.; NATH, P. Ripening of fleshy fruit: Molecular insight and the role of ethylene. Biotechnology Advances, New York, v.28, n.1, p.94-107, 2010.

CHAI, Y.; ZHANG, Q.; TIAN, L.; LI, C-L.; Xing, Y.; Qin, L.; Shen, Y.Y. Brassinosteroid is involved in strawberry fruit ripening. Plant Growth Regulator, Farnham Royal, v.69, n.1, p. 63-69, 2013.

CLOUSE, S.D. Brassinosteroid signal transduction: from receptor kinase activation to transcriptional networks regulating plant development. The Plant Cell, Rockville, v.23, n.4, p. 1219-1230, 2011.

FERREIRA, D.F. Sisvar: a computer statistical analysis system. Ciência e Agrotecnologia, Lavras, v.35, n.6, p.1039-1042, 2011.

JIANG, Y.; JOYCE, D.C.; TERRY, L.A. 1-Methylcyclopropene treatment affects strawberry fruit Decay. Postharvest Biology and Technology, Amsterdam, v.23, n.3, p.227-232, 2001.

LEE, S.K.; KADER, A.A. Pre-harvest and postharvest factors influencing vitamin $\mathrm{C}$ content of horticultural crops. Postharvest Biology and Technology, Amsterdam, v.20, n.3, p. 207-220, 2000.

LOPES, P.Z., FORNAZZARI, I.M., ALMEIDA, A.T., GALVÃO, C.W., ETTO, R.M., INABA, J., AYUB, R.A. Effect of ethylene treatment on phytochemical and ethylene-related gene expression during ripening in strawberry fruit Fragaria $\times$ ananassa cv. Camino Real. Genetics and Molecular Research, Ribeirão Preto, v.14, n.4, p.16113-16125, 2015.
MARTÍNEZ, G. A.; CIVELLO, P. M.; CHAVES, A. R.; AÑÓN, M. C. Characterization of peroxidase-mediated chlorophyll bleaching in strawberry fruit. Phytochemistry, New York, v.58, n.3, p.379-387, 2001.

MERCHANTE, C.; VALLARINO, J.G.; OSORIO, S.; ARAGUEZ, I.; VILLARREAL, N.; ARIZA, M.T.; MARTÍNEZ, G.A.; MEDINA-ESCOBAR, N.; CIVELLO, M.; FERNIE, A.R.F.; BOTELLA, M.A.; VALPUESTA, $\mathrm{V}$. Ethylene is involved in strawberry fruit ripening in organ-specific manner. Journal of Experimental Botany, Oxford, v.64, n.14, p. 4421- 4439, 2013.

MUÑOZ, C.; SÁNCHEZ-SEVILLA, J.F.; BOTELLA, M.A.; HOFFMANN, T.; SCHWAB, W.; VALPUESTA, V. Polyphenol composition in the ripe fruits of Fragaria species and transcriptional analyses of key genes in the pathway. Journal of Agricultural and Food Chemistry, Easton, v.59, n.23, p.12598-12604, 2001.

SINGH, R.; RASTOGI, S.; DWIVEDI, U.N. Phenylpropanoid metabolism in ripening fruits. Comprehensive Reviews in Food Science and Food Safety, Salt Lake City, v.9, n.4, p.398-416, 2010.

SMIRNOFF, N.; WHEELER, G.L. Ascorbic acid in plants: biosynthesis and function. Critical reviews in biochemistry and molecular biology, Boca Raton, v.35, n.4, p.291-314, 2000.

SYMONS, G. M.; DAVIES, C.; SHAVRUKOV, Y.; DRY, I. B.; THOMAS, M. R. Grapes on Steroids. Brassinosteroids Are Involved in Grape Berry Ripening. Plant Physiology, San Francisco, v. 140, pp. 150-158, 2006.

SYMONS, G.M.; CHUA, Y.J.; ROSS, J.J.; QUITTENDEN, L.J.; DAVIES, N.W.; REID, J.B. Hormonal changes during non-climacteric ripening in Strawberry. Journal of Experimental Botany, Oxford, v.63, n.2, p.695-709, 2012.

VALERO, D.; SERRANO, M. Fruit ripening. In: VALERO, D.; SERRANO, M. Postharvest biology and technology for preserving fruit quality. New York: CRC Press, 2010. p.7-42.

VILLARREAL, N.M.; BUSTAMANTE, C.A.; CIVELLO, P.M.; MARTÍNEZ, G.A. Effect of ethylene and 1-MCP treatments on strawberry fruit ripening. Journal of the Science of Food Agriculture, London, v.90, n.4, p.683-689, 2010. 
VILLARREAL, N.M.; ROSLI, H.G.; MARTÍNEZ, G.A.; CIVELLO, P.M. Polygalacturonase activity and expression of related genes during ripening of strawberry cultivars with contrasting fruit firmness. Postharvest Biology and Technology, Amsterdam, v.47, n.2, p.141$150,2008$.

XI, Z.; ZHANG, Z.; HUO, S.; LUAN, L.; GAO, X.; M.L.; FANG, Y. Regulating the secondary metabolism in grape berry using exogenous 24-epibrassinolide for enhanced phenolics content and antioxidant capacity. Food Chemistry, London, v.141, n.3, p.3056-3065, 2013.
ZHANG, Q.; WANG, H. Q.; LEN, P.; JIA, L. X. Mechanism of anthocyanins and flavonols in fruit development of strawberries. Acta Horticulturae, Leuven, v.35, n.12, p.1735-1741, 2008.

ZHU, T.; TAN, W.; DENG, X.; ZHENG, T.; ZHANG, D. LIN, H. Effects of brassinosteroids on quality attributes and ethylene synthesis in postharvest tomato fruit. Postharvest Biology and Technology, Amsterdam, v.100, n.1, p.196-204, 2015. 